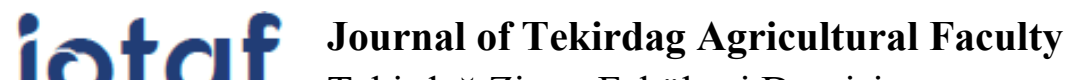 \\ Tekirdağ Ziraat Fakültesi Dergisi
}

\section{Tekirdağ Koşullarında Sorgum-Sudan Otu Melezi (Sorghum bicolor-Sorghum sudanense) Su-Verim İlişkileri}

\author{
Water-Yield Relationships of Sorghum-Sudangrass Hybrid (Sorghum bicolour-Sorghum \\ sudanense) in Tekirdağ Conditions
}

\section{Samet MORAY ${ }^{1}$, Ahmet İSTANBULLUOĞLU ${ }^{2}$}

\section{$\ddot{\mathbf{O} z}$}

Sorgum-Sudan otu melezi (Sorghum bicolor-Sorghum sudanence)'nin su-verim ilişkilerinin belirlenmesi amacıyla yapılan bu araştırma 2018-2019 yıllarında Tekirdağ Namık Kemal Üniversitesi deneme alanında (40 $59^{\prime} \mathrm{K}-27^{\circ} 34^{\prime}$ D; $20 \mathrm{~m}$ ) yürütülmüştür. Sorgum Sudan otu melezi tohumu kullanılarak tesadüf parselleri deneme desenine göre üç tekerrürlü planlanan araştırmada, bitki boyları ortalama 95-105 cm'ye ulaştığında biçimi takiben sekiz farklı sulama konusu yer almıştır. Bunlar kimi biçimleri takiben sulanan ve sulanmayan ile tüm biçimleri takiben sulanan ve susuz konular olmuştur. Araştırma sonuçlarına göre en fazla yeşil ot verimi, tüm biçimleri takiben sulanan (III) ve ilk iki biçimi takiben sulanan (II0) konulardan sırasıyla $5.03 \mathrm{ve} 5.02 \mathrm{t} \mathrm{da}^{-1}$ elde edilmiştir. İlk biçimi takiben sulamanın verim artışında önemli etkisi olmakla birlikte, en yüksek verimi alabilmek için ilk iki biçimi takiben sulamanın yeterli olacağı, tek başına ikinci veya üçüncü biçimi takiben sulamaların verim artışında etkili olmadığı, üçüncü biçimi takiben sulamaya ise gerek olmadığı görülmüştür. Bir tek sulama yapılması gerekiyorsa bunun ilk biçimi takiben yapılması önerilmektedir. İkinci biçim döneminde sulanmayıp üçüncü biçim döneminde sulama uygulaması olan konular (I0I ve 00I) üçüncü biçim döneminde hasat boyuna erişemediği için sulama uygulaması yapılamamıştır. Hiçbir biçim döneminde sulanmayan (000) konu da üçüncü biçim döneminde istenilen hasat boyuna ulaşamamıştır. Tekirdağ koşulları altında Sorgum Sudan otu melezi bitkisi kuru tarım için uygun olmadığı görülmüştür. Konulardan elde edilen mevsimlik su tüketimi ile yeşil ot verimi arasında 0.01 düzeyinde önemli $Y$ $=5.06 \mathrm{ET}+2043.3$ eşitliği ile tanımlanan ilişki bulunmuştur. Yine toplam büyüme mevsimi için, bitki su tüketimi ile yeşil ot verimi arasında su-verim ilişkisi faktörü $\left(\mathrm{k}_{\mathrm{y}}\right) 0.66$ olarak hesaplanmıştır.

Anahtar Kelimeler: Sorgum-Sudan otu, Bitki su tüketimi, Sulama, Su kullanım fonksiyonu, Su-verim ilişkisi faktörü, Trakya Bölgesi

\footnotetext{
1*Sorumlu Yazar/Corresponding Author: Samet MORAY, Tekirdağ Namık Kemal Üniversitesi, Ziraat Fakültesi, Biyosistem Mühendisliği Bölümü, Tekirdağ / Türkiye. E-mail: moraysamet@gmail.com (D) OrcID: 0000-0002-2133-5593

2 Ahmet İstanbulluoğlu, Tekirdağ Namık Kemal Üniversitesi, Ziraat Fakültesi, Biyosistem Mühendisliği Bölümü, Tekirdağ/Türkiye. E-mail: aistanbulluoglu@nku.edu.tr (iD) OrcID: 0000-0001-8080-0152.

Atıf/Citation: Moray S., Istanbulluoglu, I. Tekirdağ Koşullarında Sorgum-Sudan Otu Melezi (Sorghum Bicolor-Sorghum Sudanense) Su-Verim İlişkileri. Tekirdă̆ Ziraat Fakültesi Dergisi, 19 (1), 166-176.

*Bu çalışma Yüksek Lisans tezinden özetlenmiștir.

CBu çalışma Tekirdağ Namık Kemal Üniversitesi tarafından Creative Commons Lisansı (https://creativecommons.org/licenses/by-nc/4.0/) kapsamında yayınlanmıştır. Tekirdağ 2022 


\begin{abstract}
This research was carried in Thrace Region of Turkey (4059’ $\mathrm{K}-27^{\circ} 34^{\prime}$ ' D; 20 m) experiment area in 2018-2019 years in order to determine water-yield relationships of Sorghum-Sudan Grass Hybrid (Sorghum Bicolor-Sorghum Sudanence). In the study, which was planned with three replications according to the trial pattern of random parcels using Sorghum Sudan grass hybrid seed, eight different irrigation treatments were sawed following the form when the plant height reached an average of $95-105 \mathrm{~cm}$. These have been irrigated and rain-fed following some saw and irrigated and rain-fed after all saws. According to the results of the research, the highest yield of green weed, 5.03 and $5.02 \mathrm{t} \mathrm{da}^{-1}$ were obtained from the treatments irrigated (III) following all the saws and irrigated (II0) following the first two saws, respectively. Although the irrigation has an important effect on the increase in yield after the first saw, it has been observed that irrigation will be sufficient following the first two saws, the irrigation is not effective in the yield increase after the second or third saw, and there is no need for irrigation after the third saw. If a single irrigation is required, this should be done following the first saw. Treatments (I0I and 00I) that were not irrigated in the second saws period but third saws were irrigated, irrigation applied has not been as it could not reach the harvest size. In the non-irrigated treatment (000) could not reach harvest size in the third saw periods. Under Tekirdağ conditions, Sorghum Sudan grass hybrid plant was found to be unsuitable for dry farming. The relationship between seasonal evapotranspiration and green weed yield was statistically significant $(\mathrm{p} \leq 0.01)$ and it can be defined by equation of $\mathrm{Y}=5.06 \mathrm{ET}+2043.3(\mathrm{r}=0.82 * *)$. Again, for the total growing season, the water yield responce factor (ky) between evapotranspiration and green weed yield was calculated as 0.66.
\end{abstract}

Keywords: : Sorghum-Sudan grass hybrid, Evapotranspiration, Irrigation, Water use function, Yield response factor, Thrace Region 


\section{Giriş}

Yem bitkisi, hayvan yemi olarak, doğrudan doğruya yeşil ot olarak veya sonradan yedirilmek üzere hasat edilerek kurutulan veya silajı yapılmak üzere yetiştirilen bitkidir.

Kaba yem olarak tanımlanan iyi kaliteli yem bitkisi, hayvanlar için mineral ve vitamin kaynağı olması yanı sıra, işletmeler içinde önemli ekonomik kazanç sağlayan, en ucuz girdidir. Hayvansal üretimde işletme maliyetinin yaklaşık \% 70'ini yem masrafları oluşturmaktadır. Bu durum kaliteli yem bitkisi tarımı yapılan alanların artmasına neden olmakta, daha fazla verim ve kaliteli ürün alınmasını cazip kılmaktadır (Şamlı ve Onarbay 2011; Karahocagil ve Ege, 2004).

Dünya tarla tarımı içerisinde önemli bir yer kaplayan yem bitkileri, ekim alanı ve üretimi, Türkiye'de olması gereken düzeyin çok altında olup yaygın tarımı yapılan bitkiler yonca, fĭg ve mısırdır. Sorgum-Sudan otu melezi ise çok fazla tercih edilen ve bilinen bir yem bitkisi değildir. Oysa bu bitki dünya genelinde kuru veya sulu koşullarda yaygın olarak ekilmektedir. Özellikle sulamaya olumlu tepkiler verdiği bilinmektedir (Berenguer ve Faci, 2001).

Bullock, ve ark. (1991), Meksika'da yaptıkları araştırmalarında sorgum-sudan otu hibrit bitkisinin gelişmesi ve olgunlaşması üzerine sulama miktarının etkisinin önemli olduğunu ifade etmişlerdir. Ebenezer, ve ark. (2004), sorgum bitkisinin, su tüketimi ve dane verimi arasındaki ilişkilerin performansını incelemek için çok sayıda farklı sulama konusunu içeren bir çalışma yapmışlardır. Farre ve Faci (2006), sorgum bitkisinin orta ve fazla seviyede su kısıtı uygulanan alanlarda, mısıra göre daha fazla verim verdiğini saptamışlardır. Buradan da anlaşılacağı gibi sorgum bitkisinin kısıntılı sulama şartlarına uygun bir bitki olabileceği görülmektedir. Trakya Bölgesi'nde yarı kurak iklim şartlarının hâkim olması ve çoğunlukla kuru tarım uygulamaların yapılıyor olması, sorgum bitkisinin bu bölge için uygun bir bitki olduğu düşünülmektedir.

Demirhan (2007), Edirne'de yürüttüğü araştırmada silaj mısır (Arifiye), silajlık sorgum (Rox) ve dane tipi sorgum (Akdarı) çeşitlerinde bitki boyu, sap çapı, kardeş sayısı, yaprak sayısı, yaprak ağırlığı, hasat verimi ve kuru madde oranı incelemiştir. Arslan ve ark. (2016) Antalya'da yürüttükleri çalışmada sorgum bitkisinin farklı bitkilerle silolanarak besin içeriği yönünden kaliteli silajlar elde edileceğini saptamıştır. Aras (2017), 2015 y1lında Iğdır'da üç sorgum (Rox, Early Sumac, Leoti), iki sorgum-sudan otu melezi (Nutri Honey, Hayday) ve bir sudan otu (Gözde-80) çeşidi kullanarak yaptığı araştırmada, uygulanan sulama suyu tuzluluğunun sorgum bitkisinin bitki boyu, yaş ot ağırlığı, kuru ot ağırlı̆̆ı, tuza tolerans yüzdesi ve ham protein oranına olan etkilerini incelemiştir. Uzun ve ark., (2017), Samsun'da, sulanan yemlik mısır ve sorgum çeşitlerinin sulama suyu kullanım etkinliği ve bazı tarımsal ve besin değeri özelliklerini belirlemek için; iki mısır ve yedi sorgum çeşidini değerlendirmişler. Sulanan çeşitlerin, sulanmayan çeşitlere göre daha yüksek verim ve besleme kalitesine sahip olduklarını saptamışlardır.

Bu çalışmada, son yıllarda Trakya Bölgesi’nde giderek artan süt sığırcılığı için, taze yeşil yem ihtiyacının karşılanmasında önemli bir ekim alanı oluşturmaya başlayan sorgum-sudan otu melezinin, bölge koşullarında bitkinin su-verim ilişkisinin belirlenmesi ve bölge tarımına uygunluğunun araştırılması amaçlanmıştır.

\section{Materyal ve Metot}

\subsection{Araştırma yeri}

Araştırma Marmara bölgesi Trakya kesiminde Tekirdağ ili, Süleymanpaşa ilçesinde, Tekirdağ Namık Kemal Üniversitesi Ziraat Fakültesi deneme alanında 2018 ve 2019 yıllarında yürütülmüştür. Deneme yeri, denize 2 km uzaklıkta, 20 m yükseklikte olup 4059' kuzey enlemi ile 27³4' doğu boylamında yer almaktadır.

\subsection{Iklim şartlart}

Tekirdağ ili yarı karasal iklim tipine sahiptir. Kışları serin ve yağışlı, yazları kurak ve sıcaktır. Uzun yıllar (1940-2018) yıllık ortalama yağış miktarı yaklaşık $581.8 \mathrm{~mm}$, sıcaklık $14{ }^{\circ} \mathrm{C}$, nispi nem \%77, buharlaşma miktarı $987.3 \mathrm{~mm}$ ve rüzgâr hızı $2.7 \mathrm{~m} \mathrm{~s}^{-1}$ civarındadır (Devlet Meteoroloji İşleri, 2019). Deneme yılları boyunca ölçülen aylık yağış miktarları (2018-2019) ve uzun yıllar ortalaması Tablo l'de verilmiştir. 
Tablo 1. Araştırma yılları süresince ve çok yıllık aylık yă̆ış değerleri (mm)

Table 1. During the experimental years and long-term averages monthly precipitation values (mm)

\begin{tabular}{|c|c|c|c|c|c|c|c|c|c|c|c|c|c|}
\hline \multirow{2}{*}{ Yillar } & \multicolumn{12}{|c|}{ Aylar } & \multirow{2}{*}{ Toplam } \\
\hline & $\mathrm{I}$ & II & III & IV & $\mathrm{V}$ & VI & VII & VIII & IX & $\mathrm{X}$ & XI & XII & \\
\hline 2018 & 76.5 & 96.3 & 76.8 & 10.6 & 27.4 & 75.4 & 82.7 & - & 18.7 & 48.2 & 48.2 & 113.4 & 673.2 \\
\hline 2019 & 63.9 & 44.8 & 30.2 & 42.9 & 31.2 & 7.5 & 18.8 & - & 9.6 & 46.2 & 17.4 & 22.3 & 334.8 \\
\hline Çok yıllık & 68.8 & 54.1 & 54.4 & 40.9 & 36.7 & 37.9 & 22.8 & 13.3 & 33.6 & 62.4 & 75.4 & 81.5 & 581.8 \\
\hline
\end{tabular}

Kaynak: Devlet Meteoroloji İşleri, 2019

\subsection{Araştırmanın planlanması}

Deneme alanı pedogenetik horizon oluşmamış çok genç, killi bünyeli $(0-90 \mathrm{~cm}$ toprak profilinde ortalama \%46.2 kil, \%27.9 silt, \%25.9 kum), Entisol toprak örtüsü üzerinde yer almaktadır (Boyraz ve Sarı, 2012). Bor, tuzluluk, sodyumluluk, kireçlenme ile drenaj ve erozyon problemi yoktur. Sulama suyu kalitesi $\mathrm{T}_{2} \mathrm{~S}_{1}$ (elektriksel iletkenlik $0.5 \mathrm{dS} \mathrm{m}^{-1}$, sodyum absobsiyon oranı 7.0)'dir. Deneme alanına ait toprak nem sabiteleri Tablo 2'de, bazı kimyasal analiz değerleri ise Tablo 3'de verilmiştir.

Tablo 2. Araştırma yeri topraklarına ait tarla kapasitesi ve solma noktası değerleri Table 2. Field capacity and wilting point values of the soil of the experimental area

\begin{tabular}{|c|c|c|c|c|c|c|}
\hline \multirow{2}{*}{$\begin{array}{l}\text { Toprak } \\
\text { derinliği } \\
\text { (cm) }\end{array}$} & \multicolumn{2}{|c|}{$\begin{array}{c}\text { Tarla } \\
\text { kapasitesi }\end{array}$} & \multicolumn{2}{|c|}{$\begin{array}{c}\text { Solma } \\
\text { Noktası }\end{array}$} & \multirow[t]{2}{*}{$\begin{array}{l}\text { Hacim ağırlığ } 1 \\
\quad\left(\mathrm{gr} \mathrm{cm}^{-3}\right)\end{array}$} & \multirow{2}{*}{$\begin{array}{c}\text { Kullanilabilir } \\
\text { su } \\
(\mathrm{mm})\end{array}$} \\
\hline & $\begin{array}{l}\mathrm{Pw} \\
(\%)\end{array}$ & $\mathrm{mm}$ & $\begin{array}{l}\mathrm{Pw} \\
(\%)\end{array}$ & $\mathrm{mm}$ & & \\
\hline $0-30$ & 19.70 & 96.9 & 10.23 & 50.3 & 1.64 & 46.6 \\
\hline $30-60$ & 20.21 & 101.3 & 9.97 & 50.0 & 1.67 & 51.3 \\
\hline $60-90$ & 21.26 & 107.8 & 11.18 & 56.7 & 1.69 & 51.1 \\
\hline Toplam & & 306.0 & & 157.0 & & 149.0 \\
\hline
\end{tabular}

Tablo 3. Araştırma yeri topraklarına ait bazı kimyasal analiz değerleri

Table 3. Some chemical analysis values of the soil of the experimental area

\begin{tabular}{ccccccccc}
\hline Yillar & $\begin{array}{c}\text { Toprak } \\
\text { derinliği } \\
(\mathrm{cm})\end{array}$ & $\begin{array}{c}\text { Sature } \\
\text { toprakta } \\
\mathrm{pH}\end{array}$ & $\begin{array}{c}\text { E.C. } \\
10^{3} * 25^{\circ} \mathrm{C}\end{array}$ & $\begin{array}{c}\text { Toplam } \\
\text { tuz } \\
(\%)\end{array}$ & $\begin{array}{c}\text { Kireç } \\
\mathrm{CaCO}_{3}\end{array}$ & $\begin{array}{c}\text { Organik } \\
\text { madde } \\
(\%)\end{array}$ & $\begin{array}{c}\text { Yararlanilabilir } \\
\left(\mathrm{kg} \mathrm{da}^{-1}\right)\end{array}$ \\
\hline \multirow{2}{*}{2018} & $0-20$ & 6.9 & 492 & 0.021 & 0.92 & 0.93 & 11.2 & 128.9 \\
& $20-40$ & 6.9 & 484 & 0.018 & 0.84 & 0.87 & 6.8 & 126.8 \\
\multirow{2}{*}{2019} & $0-20$ & 7.1 & 551 & 0.022 & 0.86 & 0.90 & 12.8 & 137.5 \\
& $20-40$ & 7.0 & 520 & 0.021 & 0.82 & 0.70 & 8.0 & 139.9 \\
\hline
\end{tabular}

Araştırma tesadüf blokları deneme desenine göre üç tekerrürlü olarak yürütülmüştür. Sorgum-Sudan otu melezi (Sorghum Bicolor-Sorghum Sudanense) tohumu kullanılmıştır. Ekimler 14 Nisan 2018 ve 8 Nisan 2019 tarihlerinde yapılmıştır. Deneme parselleri 2.1 x $4.0 \mathrm{~m}$ boyutlarında olup, sıra arası $0.35 \mathrm{~m}$ ve sıra üzeri $0.20 \mathrm{~m}$ 'dir. Her parselde toplam altı sıra oluşturulmuştur. Ekim ile birlikte tüm parsellere $40 \mathrm{~kg} \mathrm{da}^{-1}$ hesabıyla $20-20-0$ gübresi (Bileşiminde \%20 azot $(\mathrm{N})$ ve \%20 fosforu $\left(\mathrm{P}_{2} \mathrm{O}_{5}\right)$ eşit oranda içeren gübre çeşidi) ve bitki boyu 40-45 cm boyuna geldiğinde ise $20 \mathrm{~kg} \mathrm{da}^{-1}$ hesabıyla üre gübresi $\left(\mathrm{CO}\left(\mathrm{NH}_{2}\right)_{2}\right.$ - \%46 azot $(\mathrm{N})$ içeren gübre çeşidi) verilmiştir. Biçimi takiben sulanan konulara sulama öncesi $10 \mathrm{~kg} \mathrm{da}^{-1}$ hesabıyla üre gübresi verilmiştir. Her iki yılda deneme alanında ön bitki olarak kışlık buğday ekimi yapılmıştır.

\subsection{Sulama konuları ve sulama uygulamast}

Sulama konularının seçiminde, bitki boylarının ortalama 95-105 cm ulaştı̆̆ındaki biçim zamanları esas alınmıştır. Ekimi takiben tüm parsellerin ilk biçiminin ardından konulu sulama uygulamalarına başlanmıştır. Biçimi takiben sulanan konular "I", sulanmayan konular "0" sembolüyle ifade edilmiştir. Deneme deseni, üç kez sulanan (III), iki kez sulanan (II0, I0I, 0II), bir kez sulanan (I00, 0I0, 00I) ve hiç sulanmayan (000) toplam sekiz konu ve üç tekerrürden oluşmuştur. 
Tekirdağ Koşullarında Sorgum-Sudan Otu Melezi (Sorghum Bicolor-Sorghum Sudanense) Su-Verim İlişkileri

Sulama uygulaması yapılacak olan konulara verilecek sulama suyu miktarının belirlenmesinde; her biçimden önce ilgili konu parsellerinin etkili kök derinliğinden $(0-90 \mathrm{~cm})$ alınan toprak örneklerindeki eksik nem miktarının tarla kapasitesine çıkarılması esas alınmıştır (Howell ve ark., 1988). Parsellerin toprak nem düzeyleri, 0-30, 30-60 ve 60-90 cm derinliklerden alınan toprak örnekleri ile gravimetrik yöntemle belirlenmiştir. Parsellere gerekli sulama suyu, göllendirmeli karık yöntemiyle uygulanmıştır.

Bitki su tüketiminin hesaplanmasında $\mathrm{ET}_{\mathrm{a}}=\mathrm{I}+\mathrm{P} \pm \Delta \mathrm{S}$ su dengesi eşitliği kullanılmıştır (Beyce ve Madanoğlu, 1980). Eşitlikte; ETa: bitki su tüketimi, I: sulama suyu, P: yağış ve $\Delta S$ : ekim ve hasat (biçim) dönemi arasında, toprak profilindeki nem değişimidir. Tüm öğeler mm'dir. Denemede yağış değerlerinin tümü etkili olarak kabul edilmiştir. Belirtilen eşitlik gereğince bulunan bitki su tüketim değerleri, her biçim döneminin başında alınan toprak örnekleri kullanılarak yı̆̆ışımlı bitki su tüketim miktarları elde edilmiştir (İstanbulluoğlu, 1996). Deneme ilk yılı 30 Eylül 2018, ikinci yılı ise 24 Eylül 2019 tarihlerinde sonlandırılmıştır.

Deneme konularından elde edilen yeşil ot miktarları Varyans analizi ve Duncan sınıflaması ile istatistiki olarak değerlendirilmiştir. Denemeden elde edilen yeşil ot değerleriyle, mevsimsel bitki su tüketim değerleri arasında doğrusal su üretim fonksiyonu ile oransal bitki su tüketimi açığı ile oransal verim azalması arasındaki ilişkiyi veren su-verim ilişkisi faktörü $\left(\mathrm{k}_{\mathrm{y}}\right)$ belirlenmiştir. Bunun için Stewart modeli esas alınarak aşağıdaki eşitlik 1 kullanılmıştır (Doorenbos ve Kassam, 1979).

$$
\left(1-\frac{\mathrm{Y}_{\mathrm{a}}}{\mathrm{Y}_{\mathrm{m}}}\right)=k_{y}\left(1-\frac{\mathrm{ET}_{\mathrm{a}}}{\mathrm{ET}_{\mathrm{m}}}\right)
$$

Eşitlikte; Ya: gerçek verim $\left(\mathrm{kg} \mathrm{da}^{-1}\right)$, Ym: maksimum verim $\left(\mathrm{kg} \mathrm{da}^{-1}\right)$, ETa: gerçek bitki su tüketimi (mm), ETm: maksimum bitki su tüketimi (mm) ve ky: su-verim ilişkisi faktörüdür. Ayrıca her bir sulama konusundan elde edilen yeşil ot miktarının; toplam evapotranspirasyona oranı ile toplam su kullanım etkinlikleri (TWUE) ve toplam sulama suyu miktarına oranı ile de sulama suyu kullanım etkinlikleri (IWUE) hesaplanmıştır (Musıck ve Dusek, 1980).

\section{Araştırma Sonuçları ve Tartışma}

\subsection{Sulamanın yeşil ot miktarı üzerine etkisi}

Deneme konularından elde edilen yeşil ot miktarları kullanılarak her yıl için yapılan birleştirilmiş varyans analizi Tablo 4' de verilmiştir. Yapılan analiz sonucunda tekerrürler arasında istatistiki anlamda bir fark çıkmamıştır. Ancak konular arasında \%1 düzeyde fark olduğu görülmüştür.

Tablo 4. Araştırma yıllarında konularda elde edilen yeşil ot miktarları ( $\mathrm{t} \mathrm{da}^{-1}$ ) Table 4. Yields of green weed obtained from treatments in the experimental years $\left(t d a^{-1}\right)$

\begin{tabular}{clcl}
\hline Sulama & \multicolumn{2}{c}{ Y1llar } & \multirow{2}{*}{ Ortalama } \\
\cline { 2 - 3 } Konular1 & 2018 & 2019 & \\
\hline III & $4.83 \mathrm{ab}$ & $5.23 \mathrm{a}$ & $5.03 \mathrm{a}$ \\
II0 & $5.28 \mathrm{a}$ & $4.76 \mathrm{a}$ & $5.02 \mathrm{a}$ \\
OII & $4.30 \mathrm{ab}$ & $4.48 \mathrm{ab}$ & $4.39 \mathrm{ab}$ \\
I0I & $4.44 \mathrm{ab}$ & $3.93 \mathrm{bc}$ & $4.19 \mathrm{ab}$ \\
I00 & $4.64 \mathrm{ab}$ & $3.78 \mathrm{c}$ & $4.21 \mathrm{ab}$ \\
OI0 & $3.81 \mathrm{~b}$ & $3.10 \mathrm{~d}$ & $3.46 \mathrm{~b}$ \\
00I & $3.67 \mathrm{~b}$ & $2.71 \mathrm{~d}$ & $3.19 \mathrm{~b}$ \\
000 & $3.73 \mathrm{~b}$ & $2.67 \mathrm{~d}$ & $3.20 \mathrm{~b}$ \\
\hline Serbestlik derecesi & 7 & 7 & 7 \\
Kareler toplam1 & 0.163 & 19.607 & 11.598 \\
Kareler ortalamas1 & 0.081 & 2.801 & 1.657 \\
F değeri & $2.418^{*}$ & $121.68^{* *}$ & $12.226^{* *}$ \\
P olasılık & $2.76^{*}$ & $4.28^{* *}$ & $4.28^{* *}$ \\
\hline
\end{tabular}

İki yıllık ortalama yeşil ot miktarları incelendiğinde, en yüksek verimler III ve II0 konularından elde edilmiştir. $\mathrm{Bu}$ konulardan elde edilen verim değerleri istatistiki olarak birinci sınıfta yer almıştır. Her iki konudan sırası ile 5.03 ve $5.02 \mathrm{t} \mathrm{da}^{-1}$ yeşil ot verimi elde edilmiştir. İkinci sınıfa giren 0 II konusundan $4.39 \mathrm{t} \mathrm{da}^{-1}$, I00 konusundan 
$4.21 \mathrm{t} \mathrm{da}^{-1}$ ve I0I konusundan $4.19 \mathrm{t} \mathrm{da}^{-1}$ yeşil ot verimleri elde edilmiştir. Son sınıfa giren konular ise bir kez sulama uygulaması yapılan $0 \mathrm{IO}$ ve 00I ile hiç sulanmayan 000 konuları olmuştur. Bu konulardan sırasıyla 3.46, 3.19 ve $3.20 \mathrm{t} \mathrm{da}^{-1}$ yeşil ot verimleri elde edilmiştir.

Sulama konularından elde edilen yeşil ot miktarları değerlendirildiğinde, bu yörede üç kez sulama suyu uygulamasının yerine, ilk biçim döneminden başlayarak ardı ardına iki kez sulama suyu uygulanması halinde de yüksek verim elde edilmiştir. Eğer bir kez sulamanın yapılması isteniyorsa, bunun birinci biçimi takiben yapılması gerekmektedir. Çünkü Duncan testi sınıflandırması sonucunda, I00 konusu ikinci sınıfta yer alırken, 0I0 ve 00I konuları son sınıfta yer almıştır. Ayrıca 00I konusu, ilk iki biçiminden sonra sulama yapılmaması nedeniyle üçüncü biçim boyuna ulaşamadığı için son biçim döneminde sulama yapılmamıştır. Bu yöre için Sorgum-Sudan otu melezinin, kuru koşullar için çok uygun olmadığı görülmüştür.

Sorgum-Sudan otu melezinin su eksikliğinin yeşil ot miktarına etkisini belirlemek amacıyla: Faci ve Fereres (1980), Dennis ve ark. (1982), Berenguer ve Faci (2001), Garofalo ve ark. (2011) ve İsmail ve ark. (2017) tarafından yapılan araştırmalarda, belirli düzeylerde uygulanan su kısıtının yeşil ot miktarı üzerinde etkili olduğu belirlenmiş̧ir. Buna göre benzer şekilde Sorgum-Sudan otu melezinin ilk ve ikinci biçim dönemlerini takip eden su kısıtlarının, yeşil ot miktarında önemli miktarda azalmalara neden olduğu gözlemlenmiş̧tir.

\subsection{Mevsimsel sulama suyu gereksinimi ve bitki su tüketimi}

Deneme konularına uygulanan sulama suyu miktarları ve mevsimlik bitki su tüketimleri Tablo 5' de verilmiş̧ir. Araştırma yıllarında ekim yapıldıktan sonra 24 Haziran 2018 ve 17 Haziran 2019 tarihlerinde tüm konularda birinci biçimler gerçekleşmiştir. Biçimlerden sonra ise konularına göre sulama suyu uygulamaları yapılmıştır.

Tablo 5. Araştırma konularına ait sulama suyu ve bitki su tüketimi miktarları (mm)

Table 5. Seasonal irrigation quantities and evapotranspiration for the irrigation treatments

\begin{tabular}{|c|c|c|c|c|c|c|c|}
\hline \multirow{3}{*}{$\begin{array}{l}\text { Sulama } \\
\text { Konuları }\end{array}$} & \multicolumn{4}{|c|}{ Araştırma Yılları } & \multirow{2}{*}{\multicolumn{2}{|c|}{ Ortalama }} & \multirow{3}{*}{$\begin{array}{c}\text { Sulama } \\
\text { Sayısı }\end{array}$} \\
\hline & \multicolumn{2}{|c|}{2018} & \multicolumn{2}{|c|}{2019} & & & \\
\hline & Sulama & ET & Sulama & ET & Sulama & ET & \\
\hline III & 345 & 655 & 336 & 547 & 340.5 & 602 & 3 \\
\hline 0II & 268 & 578 & 270 & 482 & 269.5 & 530 & 2 \\
\hline I0I* & $96^{*}$ & 406 & $89 *$ & 301 & $92.5^{*}$ & 354 & 1 \\
\hline II0 & 221 & 531 & 207 & 419 & 214.0 & 475 & 2 \\
\hline $00 I^{*}$ & $-*$ & 310 & $-*$ & 212 & $-*$ & 261 & 0 \\
\hline 0I0 & 132 & 442 & 134 & 346 & 133.0 & 394 & 1 \\
\hline $\mathrm{I} 00$ & 96 & 406 & 89 & 301 & 92.5 & 354 & 1 \\
\hline 000 & - & 310 & - & 212 & - & 261 & 0 \\
\hline
\end{tabular}

Not: * Bitki boyu yeterli olmadığından, konulu son sulama suyu uygulaması yapılmamıştır.

Araştırmanın yürütüldüğü yıllarda, konuların toprak nem içerikleri, verilen sulama suyu miktarları ve yağışlar göz önüne alınarak, her bir konunun aylık ve mevsimlik bitki su tüketim değerleri hesaplanmıştır. En az bitki su tüketimi $261 \mathrm{~mm}$ ile 000 ve 00I konularında olmuştur. Konulu sulamaları için, gerekli biçim boyuna ulaşamayan 00I ve I0I konularında son sulama uygulaması yapılamamıştır. Tüm gelişme dönemi boyunca en çok bitki su tüketimine $602 \mathrm{~mm}$ ile III konusunda olmuştur. Bunu $530 \mathrm{~mm}$ bitki su tüketimiyle 0II konusu, bilahare $475 \mathrm{~mm}$ ile II0 konusu takip etmiştir. Araştırma yılları arasında gelişme dönemi boyunca oluşan yağış farklılıkları nedeniyle bitki su tüketim değerlerinde farklılıklar olduğu gözlenmiştir.

En yüksek aylık bitki su tüketimi konularına göre farklı olmakla birlikte, önerilen konular için Temmuz ayı olmuştur. Bu ay içerisinde en yüksek bitki su tüketimi $173 \mathrm{~mm}$ ile III konusunda ikinci $150 \mathrm{~mm}$ ile II0 konusunda olmuştur. Bu konulardan III konusunun günlük su tüketim miktarı $5.6 \mathrm{~mm}$, II0 konusunun ise $4.8 \mathrm{~mm}$ olmuştur.

Araştırma sonucu elde edilen Sorgum-Sudan otu melezi bitki su tüketim değerleri; Miller ve Ottman (2010), Garofola ve ark. (2011), Shenkut ve ark., (2013), Enciso ve ark., (2015) ve Dündar (2019) gibi araştırmacıların elde ettikleri değerler ile benzerlik göstermiştir. Farklı iklim ve toprak koşullarının etkisi altında yapılan araştırmalarda, Sorgum-Sudan otu melezinin bitki su tüketimi miktarı 360-884 mm arasında değiştiği gözlenmiştir. 


\subsection{Su üretim fonksiyonu ve su-verim ilişkisi faktörü ( $\left.k_{y}\right)$}

Araştırma yıllarına ait mevsimlik bitki su tüketimi ve yeşil ot verimi miktarları kullanılarak elde edilen su üretim fonksiyonu Şekil 1'de verilmiştir. Yeşil ot miktarı ve bitki su tüketimi arasında Y = 5.061 ET + 2043.3 (r $=0.82 * *)$ gibi pozitif lineer bir ilişki bulunmuştur. $\mathrm{Bu}$ eşitliğin kullanılmasıyla bitki su tüketimine karşılık Sorgum-Sudan otu melezi yeşil ot miktarını tahmin etmek mümkündür.

Sulama programına, toprak ve iklim değişkenlikleri gibi etmenlere bağlı olarak, Tülücü (1985)'de belirttiği gibi su-verim ilişkisi doğrusal ya da eğrisel olabilmekle birlikte, Sorgum-Sudan otu melezi için yapılan çalışmalarda Faci ve Fereres (1980), Dennis ve ark., (1982), Myers ve ark., (1984) ve Berenguer ve ark., (2001) tarafından da benzer ilişkiler elde etmiştir.

Deneme konularından elde edilen bitki su tüketimi ve yeşil ot miktarları kullanılarak belirlenen, oransal bitki su tüketimi açığı ile oransal verim azalmasını ifade eden su-verim ilişkisi faktörü ( $\mathrm{k}_{\mathrm{y}}$ ), toplam büyüme mevsimi için 0.66 olarak hesaplanmış ve Şekil 2'de verilmiştir.

Su-verim ilişkisi faktörü 2018 ve 2019 yılları içinde sırasıyla 0.53 ve 0.75 olarak hesaplanmıştır. 2019 yılında ky değerinin yüksek olmasının nedeni çalışma dönemi boyunca düşen yağış miktarının 2018 yılına göre çok az olmasıdır. Bu durum bitkinin su kısıtına karşı daha duyarlı olmasını kılmıştır.

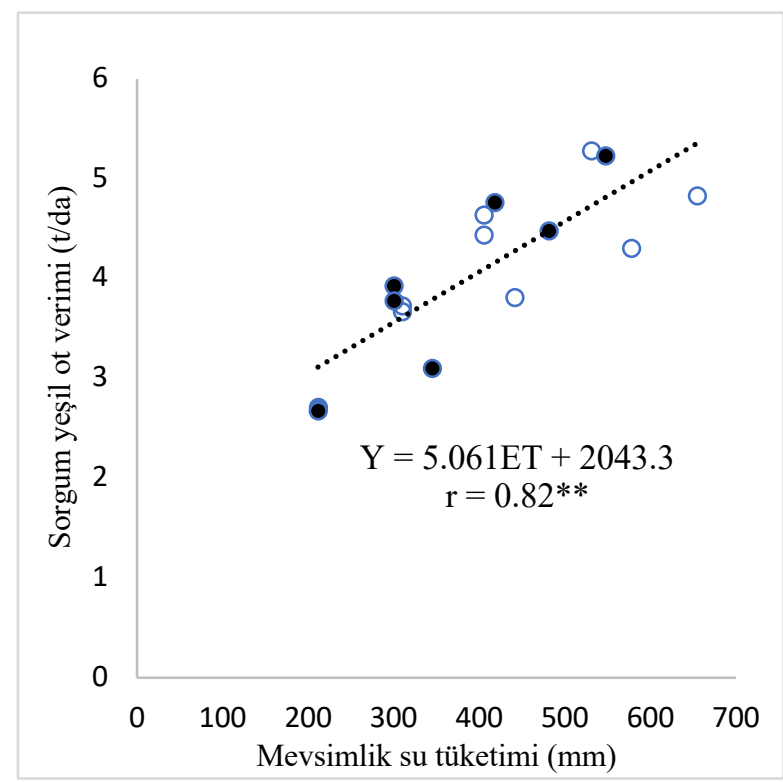

Figure 1. Relationships between seasonal evapotranspiration and green weed yield

\section{Şekil 1. Bitki su tüketimi ve yeşil ot miktarına ait mevsimlik su üretim fonksiyonu}

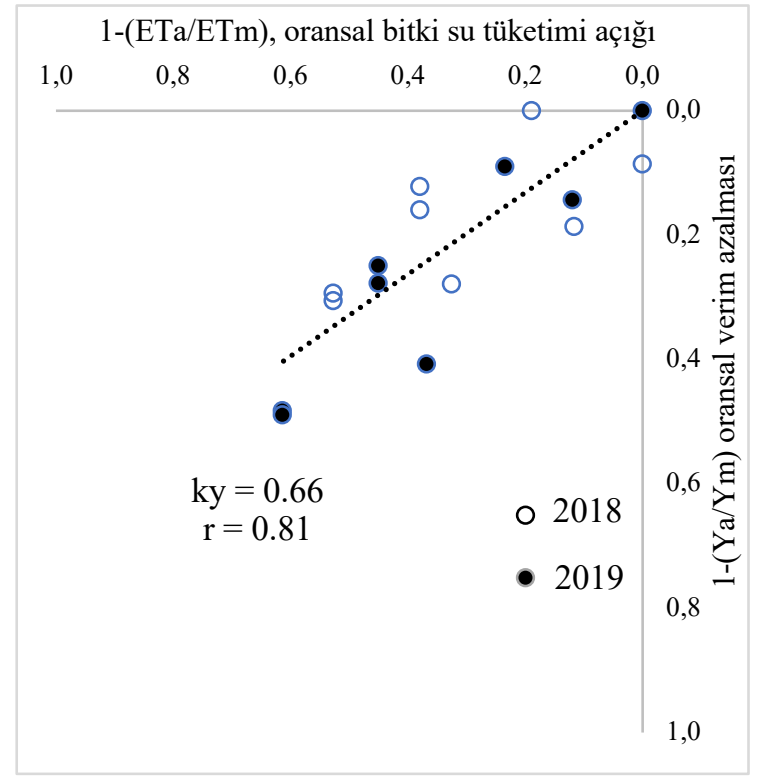

Figure 2. Relationships between relative evapotranspiration and green weed yield decrease

\section{Şekil 2. Bitki büyüme mevsimine ait ortalama} su-verim ilişkisi faktörü

\subsection{Sorgum-Sudan otu melezinin su kullanım etkinliği ve su tasarrufu}

Deneme konularından elde edilen verim azalması ve sulama suyu tasarrufları, Tablo 6' da verilmiştir. Konular arasında en düşük verim azalması, ilk iki biçimi takiben sulanan II0 konusunda ortalama $\% 0.2$ olmuştur. Bu konun sulama suyu tasarrufu ise $\% 37.2$ oranında olmuştur. Bir tek sulama yapılması gerekiyorsa ve bunun ilk biçimi takiben yapılması önerilen I00 konusunda \%72.8 gibi yüksek bir su tasarrufuna karşılık \%16.3 verim azalması kaydedilmiştir. Hiç sulama yapılmayan 000 konusunda ortalama yeşil ot miktarı azalması \%36.4 oranında olmuştur. 
Tablo 6. Araştırma konularından elde edilen verim azalması ve sulama suyunda tasarruf değerleri Table 6. Yields of green weed decrease and irrigation water saving for the treatments in the experimental years

\begin{tabular}{|c|c|c|c|c|c|c|}
\hline \multirow{3}{*}{$\begin{array}{l}\text { Sulama } \\
\text { konuları }\end{array}$} & \multicolumn{3}{|c|}{ Verim azalması (\%) } & \multicolumn{3}{|c|}{ Sulama suyu tasarrufu (\%) } \\
\hline & \multicolumn{2}{|c|}{ Yillar } & \multirow{2}{*}{ Ortalama } & \multicolumn{2}{|c|}{ Yillar } & \multirow{2}{*}{ Ortalama } \\
\hline & 2018 & 2019 & & 2018 & 2019 & \\
\hline III & 8.5 & - & - & - & - & - \\
\hline 0II & 18.6 & 14.3 & 12.7 & 22.3 & 19.6 & 21.0 \\
\hline I0I & 15.9 & 24.9 & 16.7 & 72.2 & 73.5 & 72.8 \\
\hline II0 & - & 9.0 & 0.2 & 35.9 & 38.4 & 37.2 \\
\hline 00I & 30.5 & 48.2 & 36.2 & 100.0 & 100.0 & 100.0 \\
\hline 0I0 & 27.8 & 40.7 & 31.2 & 61.7 & 60.1 & 60.9 \\
\hline $\mathrm{I} 00$ & 12.1 & 27.7 & 16.3 & 72.2 & 73.5 & 72.8 \\
\hline 000 & 29.4 & 49.0 & 36.4 & 100.0 & 100.0 & 100.0 \\
\hline
\end{tabular}

Denemede ele alınan konulara ilişkin toplam su kullanım etkinlikleri (TWUE) ve sulama suyu kullanım etkinlikleri (IWUE) yıllar ve yılların ortalaması olarak Tablo 7' de verilmiştir. Çizelgede görüldüğü gibi IWUE değerleri TWUE değerlerine göre daha yüksektir. Bunun nedeni bitki su tüketim miktarının sulama suyu miktarından daha büyük olmasıdır.

\section{Tablo 7. Araştırma konularından elde edilen TWUE ve IWUE değerleri $\left(\mathrm{kg} \mathrm{m}^{-3}\right)$}

Table 7. The total water use efficiencies (TWUE) and the irrigation water use efficiencies (IWUE) for the treatments in the experiments years $\left(\mathrm{kg} \mathrm{ha}^{-1} \mathrm{~mm}^{-1}\right)$

\begin{tabular}{|c|c|c|c|c|c|c|}
\hline \multirow{3}{*}{$\begin{array}{c}\text { Sulama } \\
\text { konuları }\end{array}$} & \multicolumn{3}{|c|}{ Toplam su kullanım etkinliği } & \multicolumn{3}{|c|}{ Sulama suyu kullanım etkinliği } \\
\hline & \multicolumn{2}{|c|}{ Yillar } & \multirow{2}{*}{ Ortalama } & \multicolumn{2}{|c|}{ Yillar } & \multirow{2}{*}{ Ortalama } \\
\hline & 2018 & 2019 & & 2018 & 2019 & \\
\hline III & 7.4 & 9.6 & 8.4 & 14.0 & 15.6 & 14.8 \\
\hline 0II & 7.4 & 9.3 & 8.3 & 16.0 & 16.6 & 16.3 \\
\hline $\mathrm{I} 0 \mathrm{I}$ & 10.9 & 13.6 & 11.8 & 46.2 & 44.2 & 45.3 \\
\hline II0 & 9.9 & 11.4 & 10.6 & 23.9 & 23.0 & 23.5 \\
\hline 00I & 11.8 & 12.8 & 12.2 & - & - & - \\
\hline 0I0 & 8.6 & 8.9 & 8.8 & 28.9 & 23.1 & 26.2 \\
\hline $\mathrm{I} 00$ & 11.4 & 12.6 & 11.9 & 48.3 & 42.5 & 45.5 \\
\hline 000 & 12.0 & 12.6 & 12.3 & - & - & - \\
\hline
\end{tabular}

Ortalama değerler kullanılarak ele alınan sulama konuları arasında en yüksek TWUE değeri $12.3 \mathrm{~kg} \mathrm{~m}^{-3}$ olarak kuru koşullardaki 000 konusunda olmuştur. Sulama uygulaması yapılan konular incelendiğinde ise, en yüksek değer $11.9 \mathrm{~kg} \mathrm{~m}^{-3}$ ile I00 konusu, en düşük değer $8.3 \mathrm{~kg} \mathrm{~m}^{-3}$ ile 0 II konusu olmuştur. Bunun anlamı, ilk biçimi takiben sulama suyu verilmemesinden dolayı verim azalması olmuştur. Bu nedenle ilk biçimi takiben yapılan sulama önem taşımaktadır.

Aynı şekilde en yüksek IWUE değeri $45.5 \mathrm{~kg} \mathrm{~m}^{-3}$ ile I00 konusunda ve en düşük değeri ise $14.7 \mathrm{~kg} \mathrm{~m}^{-3}$ ile III konusunda elde edilmiştir. Bunun anlamı, bitki gelişme dönemi başlangıcında toprak neminin yeterli olması gerektiğidir. Burada bir kez daha ilk biçimi takiben yapılan sulamanın önemli olduğu görülmüştür. Fakat belli bir sulama suyu ve toprak nem miktarından sonra uygulanacak sulama suyu ile ürün artışı sağlanamayacağı ve Sorgum-Sudan otu melezinin her gelişme döneminde sudan eşit olarak yararlanamadığını göstermektedir (Tülücü, 1985).

Sorgum-Sudan otu melezi bitkisinin farklı çeşitleri üzerine yeterli sayıda çalışma olmamakla birlikte yapılan diğer araştırmalarda; Ismail ve ark., (2017) sulama suyu kullanım etkinliğinin (IWUE) artmasıyla ürün veriminin azalma gösterdiğini saptamıştır. Ancak Dennis ve ark., (1982) bitki su tüketiminin maksimumun altına düştüğünde su kullanım etkinliğinin (IWUE) sürekli olarak düştüğünü gözlemiştir. Buradan sorgum bitkisinin çeşitlerine de bağlı olarak toprak ve iklim özellikleri farklı olan bölgeler de su kullanım etkinliğinin farklılıklar gösterebileceği 

anlaşılmaktadır. Sorgum Sudan otu melezi su-verim ilişkileri literatür farklılıklarının olası etkileri üzerine bir değerlendirme yapılamamıştır.

\section{Sonuç}

Araştırmanın yürütüldüğü yıllarda konulardan elde edilen Sorgum-Sudan otu melezi yeşil ot miktarlarına göre yapılan birleştirilmiş varyans analizi ve Duncan testi sınıflandırması sonucu III konusu en yüksek miktarı vermiştir. Yapılan Duncan testi sınıflandırması sonucunda III konusu ile II0 konusu aynı sınıfta yer almıştır. Dolayısıyla her iki konu arasında istatiksel olarak bir fark bulunmamıştır.

Herhangi bir su kısıtının olmadığı III tanık konusuna toplam 340 mm sulama suyu uygulanmış ve mevsimlik bitki su tüketimi $602 \mathrm{~mm}$ olarak belirlenmiştir. Bu konunun aylık en yüksek su tüketimi Temmuz ayında $173 \mathrm{~mm}$ olarak bulunmuştur. Bu konudan ortalama $5.03 \mathrm{t} \mathrm{da}^{-1}$ yeşil ot miktarı elde edilmiştir. Benzer şekilde ilk ve ikinci biçimleri takiben sulanan II0 konusuna toplam $214 \mathrm{~mm}$ sulama suyu uygulanmış ve mevsimlik bitki su tüketimi $475 \mathrm{~mm}$ olarak saptanmıştır.

Sulama konularından elde edilen yeşil ot miktarı ile bitki su tüketimi arasında Y $=5.061 \mathrm{ET}+2043.3(\mathrm{r}=$ $0.82^{* *}$ ) eşitliği ile ifade lineer ilişki bulunmuştur. Su-verim ilişkisi faktörü $\mathrm{k}_{\mathrm{y}}=0.66$ olarak hesaplanmıştır. Bu değer 2018 ve 2019 yıllarında sırasıyla 0.53 ve 0.75 olmuştur. En yüksek TWUE ve IWUE değerleri ilk biçimi takiben bir kez sulanan I00 konusunda elde edilmiştir.

Sorgum-Sudan otu melezinin toprak nem eksikliğine duyarlı bir bitki olduğu ve en duyarlı döneminin birinci ve ikinci biçimleri takip eden dönemlerin olduğu görülmüştür. Yüksek verim elde etmek için büyüme mevsimi boyunca gerçekleştirilecek biçimleri takiben sulanması gerekmektedir. Bunun için ilk biçimin Haziran ayı, ikinci biçimin Temmuz ayı ikinci yarılarında, üçüncü biçimin ise Ağustos ayı son veya Eylül ayı ilk haftasında yapılmasını takiben sulama yapılmasıdır.

Su kaynaklarının kısıtlı olduğu koşullarda, ilk iki biçimi takiben yapılan sulamalardan sonra üçüncü biçimi takiben sulama yapılmayabilir. Şayet bir kez sulama imkânı olması halinde ise bu sulamanın mutlaka ilk biçimi takiben yapılaması gerekmektedir. 
Kaynakça

Aras, İ., (2017). Silajlık Sorgum (Sorghum Sp.)’un Verim ve Kalitesi Üzerine Farklı Sulama Suyu Tuzluluk Seviyelerinin Etkileri. (Yüksek Lisans Tezi), Iğdır Üniversitesi Fen Bilimleri Enstitüsü, Iğdır.

Arslan M., Erdurmuş C., Öten M, Aydınoğlu B. ve Çakmakçı S (2016). Sorgum ve Bazı Bitkilerin İle Farklı Oranlarda Karışımlarından Hazırlanan Silajların Kalite Özellikleri. Tekirdağ Ziraat Fakültesi Dergisi. 14(02): 34-41

Berenguer, M.J., J.M. Faci, (2001). Sorghum (Sorghum Bicolor L. Moench) Yield Compensation Processes Under Different Plant Densities and Variable Water Supply. Europen Journal of Agronomy, Volume 15, Issue 1: Pages 43-55.

Beyce, Ö., K. Madanoğlu, (1980). Bitki Su Tüketiminin Saptanması. TOPRAKSU Araştırma Ana Projesi, No: 433, Ankara.

Boyraz, D., H. Sarı, (2012). Tekirdağ Değirmenaltı-Muratlı Kavşağı Çevre yolunu Oluşturan Katenadaki Toprakların Fiziksel ve Zemin Özelliklerinin Değerlendirilmesi. Journal of Tekirdağ Agricultural Faculty, 2012, 9(3), pp 68-78.

Bullock, D.G., M. Dugarte-Fernadez, J.L. Fowler, (1991). Growth Analysis of Irrigated Sorghum- Sudan grass. Biotron Institute Kyushu University NII-Electronic Library Service, Biotironics Vol. 20: p. 9-17.

Demirhan, F., (2007). Silajlık Olarak Kullanılabilecek İkinci Ürün Bazı Yem Bitkisi Türlerinin Morfolojik Özellikleri ve Ot Verimi Üzerine Araştırmalar, (Yüksek Lisans Tezi), Namık Kemal Üniversitesi Fen Bilimleri Enstitüsü, Tekirdağ.

Dennis, P.G, D.G. Watts, C.Y. Sullivan, J.R. Gilley, (1982). Moisture Deficits and Grain Sorghum Performance: Evapotranspiration-Yield Relationships. Acsess Digital Library, Vol. 74, No. 5, p 815-820. September 1982, doi:10.2134/agronj1982.00021962007400050011x.

DMİ, (2019). Tekirdağ İli 2018 ve 2019 Yılı Metorolojik Rasat Özeti. Aylık Toplam Ortalama Sıcaklık, Yağış, Nem, Rüzgâr Hızı Değerleri. Tarım ve Ormancılık Bakanlığı Meteoroloji İşleri Genel Müdürlüğ̈. Tekirdağ.

Dündar, M., (2019). Kısıntılı Sulama Tekniğinin İkinci Ürün Tatli Sorgumun Biyokütle ve Biyoetanol Verimine Etkilerinin Araştırılması (Yüksek Lisans Tezi), Çukurova Üniversitesi Fen Bilimleri Enstitüsü, Adana.

Doorenbos, J., A.H. Kassami, (1979). Yield Respose to Water. Food and Agriculture Organization of the United Nations. Irrigation and Drainage Paper; 33, Roma.

Ebenezer, A., A. Ayorinde, A. Olufayob, (2004). Evaluation of Two Temperature Stress Indices to Estimate Grain Sorghum Yield and Evapotranspiration. Access Digital Library, Vol. 96, No. 5: p. 1282-1287. Sept, 2004. doi:10.2134/agronj2004.1282.

Enciso, J., J. Jifon, L. Ribera, S.D. Zapata, G.K. Ganjegunte, (2015). Yield, Water Use Efficiency and Economic Analysis of Energy Sorhgum in The South Texas. Scienece Direct Journals and Books, Biomass and Bioenergy. Volume: 81 Pages: 339-344.

Faci, J.M., E. Fereres, (1980). Responses of Grain Sorghum to Variable Water Supply Under Two Irrigation Frequencies. Irrigation Sciene by Springer Link, (1), 49-159.

Farre, I. ve Faci, J.M. (2006). Comparative response of maize (Zea mays L.) and sorghum (Sorghum bicolor L. Moench) to deficit irrigation in a Mediterranean Environment. Agricultural Water Management. 83(1-2), 135-143.

Garofalo, P., A.V. Vonella, S. Ruggieri, M. Rinaldi, (2011). Water and Radiation Use Efficiencies of Irrigated Biomass Sorghum in a Mediterranean Environment. Italian Journal of Agronomy; Volume 6, No. 2, pages 134-139.

Howell T.A., Copeland K.S., Schneider A.D., Dusek D.A., (1988). Sprinkler Irrigation Management for Corn Southern Great Plaine. International Summer Meeting og The ASEA, Rushmore Plaza Civic Center, Rapid City, SD. USA.

Howell, T.A., H.A. Cuenca, K.H. Solomon, (1990). Crop Yield response.Management of farm irrigation systems. Trans. ASAE Monograph Chap. S. USA.

Kanber, R., O. Tekinel, R. Baştuğ, S. Önder, N. Baytorun, (1989). Peaunt Yield as Affeoted by deficit Irrigation Soil Texture. Sowing Date and Irrigation Interval "Theory and practice. Edit by J.R. Rydzeuski and cF. Ward", Southampton.

Karahocagil, P., H. Ege. 2004. Karma Yem Sanayi. Tarımsal Ekonomi Araştırma Enstitüsü, Bakış. Sayı: 5 (9): 1-4.

İstanbulluoğlu, A., (1996). Bitki Su Tüketiminin Doğrudan Ölçüldüğü, Tarla Deneme Parselleri Yöntemi, Trakya Üniversitesi Ziraat Fakültesi Yayınları, No: 240, Tekirdağ.

Ismail, S.M., F.S. Nakhlawy, J.M. Basahi, (2017). Sudan Grass and Pearl Millets ductivity Under Different Irrigation Methods With Fully Irrigation and Stresses in Arid Regions. Japanese Society of Grassland Science, Grassland Science, Vol.64: pp 29-39.

Shenkut, A., K. Tesfoye, F. Abegaz, (2013). Determination of Water Requirement and Crop Coefficient for Sorghum (Sorghum Bicolor L.). At Sciene, Techology and Arts Research Journal. Vol: 12, No 3. Paper 16-24.

Şamlı H. E. ve Onarbay O. N. (2011). Farklı Depolama Şartlarının Bazı Protein Kaynaklı Yem Hammaddelerinin Özellikleri Üzerindeki Etkilerinin Belirlenmesi, Tekirdağ Ziraat Fakültesi Dergisi, 8 (3): 40-45;

Miller, A.N., M.J. Ottman M.J.,(2010). Irrigation Frequency Effects on Growth and Ethanol Yield in Sweet Sorghum. Acsess Digital Library, Vol. 102 No. 1; p. 60-70. Jan 2010. doi:10.2134/agronj2009.0191 
Tekirdağ Koşullarında Sorgum-Sudan Otu Melezi (Sorghum Bicolor-Sorghum Sudanense) Su-Verim İlişkileri Myers, R.J.K., M.A. Foale, A.A. Done, (1984). Responses of Grain Sorghum to Varying Irrigation Frequency in the Ord İrrigation Area. II. Evapotranspiration, Water Use Efficiency and Root Distribution of Different Cultivars. Crop \& Pasture Sciene, Australian Journal of Agricultural Research, 35(1): p. 31-42.

Musick, J.T., D.A. Dusek, (1980). Irrigated Corn Yield Response to Water. Transactious of the ASAE. Vol. 23, No: 1, Washington.

Tülücü, K., (1985). Tarımsal Sulamada Kısıntılı Su Uygulaması Su-Üretim Fonksiyonu Kavramı ve Kaynakların En İyi Kullanımı. Doğa, Türk Tarım ve Ormancılık Dergisi, 9(1).

Uzun, F., A.V. Garipğlu, N. Ocak, (2017). Water use efficiency, yield, and nutritive value of maize and sorghum cultivars irrigated in a shallow soil. Anadolu Journal of Agricultural Sciences. 32 (2017), 358-366 p. 